Л. В. Царьова

\title{
ЛІНГВІСТИЧНІ ОСОБЛИВОСТІ АБРЕВІАТУР І СКОРОЧЕНЬ В АНГЛІЙСЬКИХ РАДІОМОВНИХ ПОВІДОМЛЕННЯХ АТІS
}

Царьова Л. В. Лінгвістичні особливості абревіатур і скорочень в англійських радіомовних повідомленнях ATIS.

У статті розглянуто сучасні класифікації типів абревіатур і скорочень, уживаних в англійських радіомовних повідомленнях ATIS. Аналіз різних типів абревіатур i скорочень дав змогу дійти висновку, що поряд зі значною кількістю ініціальних абревіатур у фразеології радіоповідомлень англійською мовою широкого вжитку здобули еліпсні й ініціально-еліпсні скорочення.

Ключові слова: повідомлення ATIS, абревіатура, скорочення, еліпсні й ініціально-еліпсні скорочення.

Царева Л. В. Лингвистические особенности аббревиатур и сокращений в английских радиосообщениях ATIS.

В статье рассматриваются современные классификации типов аббревиатур и сокращений, применяемых в английских радиосообщениях ATIS. Анализ различных типов аббревиатур и сокращений позволил сделать вывод, что наряду с большим количеством инициальных аббревиатур во фразеологии радиосообщений на английском языке широкое использование получили эллипсные и инициальноэллипсные сокращения.

Ключевые слова: сообщение ATIS, аббревиатура, сокращение, эллипсные и инициально-эллипсные сокращения.

Tsaryova L. V. Linguistic peculiarities of abbreviations and acronyms in English ATIS radiotelephony messages.

The article analyzes the current classification of the types of abbreviations and acronyms used in the English radio ATIS messages. Analysis of different types of abbreviations and acronyms led to the conclusion that, along with lots of acronyms in the English phraseology of radiotelephony elliptical and initially-elliptical abbreviations are widespread.

Key words: ATIS messages, abbreviation, acronym, elliptical and initially-elliptical abbreviations.

У зв'язку 3 розвитком авіаційної індустрії на початку XXI століття виникла необхідність покращити рівень англійської професійної мови задля підвищення надійності ведення радіообміну в різних країнах світу, оскільки відповідно до постанов Міжнародної організації цивільної авіації (IКАО) міжнародна радіотелефонна комунікація пілотів та авіадиспетчерів повинна відбуватися 
англійською мовою [7, с. 51].

Швидкий розвиток науки в кінці XX ст. й на початку XXI століття зумовив потребу у зручних для оперування назвах нових винаходів, концепцій, організацій тощо. Ця потреба сприяла виникненню різних абревіатур, скорочень й усічень. Такий лінгвістичний процес відбувався й в англійській мові радіобміну, тому однією 3 характерних особливостей авіаційної мови $є$ широке застосування різних видів скорочень, усічень, абревіатур і т. ін. мовних явищ.

Структура авіаційної англійської мови досліджувалася зарубіжними науковцями (Г. Емері, М. Міцутомі, К. О’Брайен, Дж. Мелл); лінгвістичні особливості мови радіообміну загалом викликали зацікавлення таких учених, як-от: Г.Г. Снчева, Г. Г. Кириченко, О. В. Ковтун; деякі - О.С. Кубрякова, Т. А. Мальковська, О. В. Акімова - вивчали авіаційну англійську мову в порівнянні з російською; окремі аспекти вживання різних видів скорочень, усічень, абревіатур тощо були висвітлені в наукових працях Е. Вайнера, Д. Вілтона, Д. Крістела, С. Паркера, С. Пінкера, Дж. Сімпсона. Проте особливості вживання різних видів скорочень, усічень, абревіатур і т. ін. англійських радіомовних повідомлень ATIS наразі не отримали ретельного дослідження в науковій літературі.

Зарубіжні вчені Д. Крістел і С. Пінкер фіксують такі лексичні явища, як ініціалізм (initialism), акронім (acronym) та абревіатура (abbreviation) [8, с. 48]. Спочатку термін «акронім» використовувався для ініціалізмів, що вимовлялися словом, потім став загальною назвою для всіх типів абревіатур, скорочень, усічень. У зарубіжній лінгвістиці досі немає єдиної думки щодо витлумачення термінів «акронім», «ініціалізм», «абревіатура» [8, с. 50]. Здебільшого ці поняття замішуються, науковці послуговуються переважно терміном «акронім» для всіх типів. Відтак, розв'язання цієї проблеми триває.

Розмаїття типів абревіатур зумовило потребу в їхній класифікації. Г. Г. Кириченко виокремлює три типи абревіатур, характерні для радіообміну англійською мовою: 1) ініціальні звукові; 2) ініціальні літерні; 3) складові [3, с. 66]. Ширшу класифікацію скорочень й абревіатур запропонувала Т. О. Мальковська. На думку дослідниці, тяжіння мови радіообміну до структурного скорочення висловлення виявляється у значній кількості абревіатур [6, с. 12]. Абревіатури, засвідчені в англійських діалогах, належать здебільшого 
до ініціального типу, наприклад: ETO - Astimated Time Over smth, FIR - Flight Information Région, etc. Рідше трапляються аброморфемноеліпсні скорочення: Nosig - No Significant Changes; ініціально-еліпсні: VDF - Very High Frequencv Direction Finding Station; аброморфемні: Wilco - will comply, ініціально-словесні: cavok - ceiling and visibility OK; умовні: VOLMET - Meteorological Information for Aircraft in Flight [6, с. 12]. Крім того, зафіксовано низку англійських абревіатур у російськомовних повідомленнях ATIS.

Грунтовна класифікація скорочень представлена у праці О. В. Ковтун, яка кваліфікує абревіатури як ознаку мовної економії на морфологічному рівні. У фразеології радіомовлення науковець виокремлює ініціальні, еліпсні, аброморфемні та ініціально-словесні скорочення, 3-поміж яких вирізняються за кількістю ініціальні: $A T I S$ Automatic Terminal Information Service, DME - Distance Measuring Equipment тощо [4, с. 309]. Еліпсні скорочення, на думку О. В. Ковтун, являють собою усічену структуру вихідного слова 3 одним чи кількома вилученими компонентами. У цій групі скорочень диференціює такі підвиди: аброморфемно-еліпсні (SIGMET Significant Meteorological Information); ініціально-еліпсні, що містять у своїй структурі окремі 3 ініціальних елементів вихідного поняття (VDF - Very High Frequency Direction Finding Station, VOR - Very High Frequency Omnidirectional Radio Range) [4, c. 309].

Аброморфемні скорочення, згідно 3 позицією дослідниці, складаються 3 початкових частин слів вихідного слова чи словосполучення: Lat (latitude), Long (Longitude). Ініціально-словесне скорочення (cavok - ceiling and visibility $O K$ ), що складається 3 початкових літер і цілого слова, використовується в повідомленнях із забезпечення метеорологічною інформацією екіпажів літаків. Це скорочення має усталене значення і відповідає таким метеорологічним умовам: видимість не менше десяти кілометрів, відсутність хмарності нижче 1500 метрів і купчасто дощової хмарності [4, с. 310].

О. С. Кубрякова досліджувала абревіатури й скорочення у двох ракурсах: відповідно до номінативної мети абревіатури й залежно від способів скорочень. Різноманітні види скорочених мовних одиниць не стільки утворюють нові лексичні значення, скільки, за твердженням науковця, змінюють спосіб представлення й відображення дійсності. Відповідно до номінативної мети абревіатури можна класифікувати 
так: назви організацій, структур, документів, наприклад: ANC (Air Navigation Commission) - AHK (аеронавігаційна комісія); терміни зі сфери виконання польотів, організації повітряного руху тощо, наприклад: ATC (Air Traffic Control) - KПР (керування повітряним рухом); найменування, які використовуються в радіотелефонному зв'язку між пілотами та диспетчерами [5, с. 45].

Залежно від способів скорочень в англійській авіаційній термінології О.С. Кубрякова виокремлює такі різновиди абревіатур: ініціальні (284 од.): ACC - area control center; поскладові (249 од.): $E N G$ - engine; акроніми (101 од.): EASA - European Aviation Safety Authority; подвійне скорочення (20 од.): ELT(AD) - Automatic Deployable ELT, аварійний привідний радіомаяк автоматичного розгортання; ініціальноцифрові (101 од.): TM5 = TM AIRCRAFT [5, с. 42].

Повідомлення ATIS містять інформацію щодо назви аеродрому, код аеродрому, напрямок і швидкість вітру, видимість, хмарність, температуру, важливу метеорологічну інформацію за необхідністю тощо. Для передачі інформації в цих повідомленнях вживаються різні типи абревіатур і скорочень замість повних назв погодних явищ, назв типів метеоповідомлень, стану ЗПС, назв служб тощо.

Для повідомлень ATIS характерні різні типи скорочень, а саме: поскладове (SN - Snow), усічення двох голосних (ABV - Above); ініціальне (AGL - Above Ground Level, MOR - Meteorological Optical Range); ініціально-еліпсне (NOTAM or NoTAM - Notice to Airmen); акронімне (CADAS - Computer Controlled Avionics Data Acquisition System); подвійне (CANAC - Computer Assisted National ATC Center); ініціально-цифрове (18R - Runway 18 Right) (2, с. 107).

В авіаційній англійській мові натрапляємо на низку абревіатур, що вимовляються як слово, тобто акронім: GUMPS - Gas, Undercarriage, Mixture, Propeller, Seat belts and Switch; ASSIST Acknowledge, Separate, Silence, Information, Support, Time (2, c. 142).

Класифікація абревіатур вплинула на способи перекладу абревіатур авіаційної англійської мови. Г. Г. Снчева вважає абревіацію репрезентативним різновидом безафіксного способу творення авіаційних термінів, виокремивши понад 755 одиниць. Найчастіше спостерігається переклад відповідною повною формою слова або словосполучення (137 од.): GA - gliding angle - кут планерування; метод прямого запозичення (192 од.): перенесення оригінальної форми

С Л. В. Царьова, 2015. 
скорочення в текст перекладу зафіксовано при передачі марки літальних апаратів (B737-200), авіаційних двигунів (TRE331-14), пілотажно-навігаційного обладнання (AN/AC182, LRN500); описовий метод (102 од.): INAD - особа, якій відповідними органами відмовлено у праві на в’ізд до держави; транскодування скорочення (96 од.), наприклад, AEROSAT - Aeronautical Satellite Council - AEPOCAT Рада з використання супутників для потреб авіащиї; переклад відповідним скороченням (89 од.): $A J E-$ ПРД (повітряно-реактивний двигун); транскодування повної форми скорочення (71 од.): $B O A C$ (British Overseas Airways Company) - авіаційна компанія; створення нового українського скорочення (68 од.): $R W Y$ - runway - $3 П C$ (злітнопосадкова смуга) [1, с. 14].

Такий вид перекладу зумовлений тим, що в українській мові наразі немає багатьох відповідників англійським термінам, оскільки українська авіаційна терміносистема нині перебуває на етапі свого активного становлення. Саме тому перекладачеві зручніше запозичити, транскодувати мовну одиницю або описати процес чи дію, яку вона передає, для правильного та повного ii розуміння. Гадаємо, що розв'язання проблеми перекладу абревіатур і скорочень у фразеології радіомовлення сприятиме якісному навчанню майбутніх авіаційних спеціалістів розумінню і вживанню їх у повідомленнях ATIS.

Радіомовні терміни й концепти переважно маніфестуються у скороченій формі, повну назву складніше передавати й розуміти у процесі оперування повітряним рухом. У такий спосіб відбувається економія не тільки на лінгвальному рівні, а й у часі, що важливо, зокрема, в аварійних ситуаціях. Різні типи абревіатур роблять мову радіообміну точною, однозначною й лаконічною, що відповідає вимогам IКАО.

Аналіз абревіатур і скорочень, використовуваних у повідомленнях ATIS, дав змогу констатувати, що поряд зі значною кількістю ініціальних абревіатур у фразеології радіоповідомлень англійською мовою активізуються еліпсні й ініціально-еліпсні скорочення. Їх дослідженню варто приділяти належну увагу під час підготовки майбутніх авіаційних спеціалістів.

Подальше вивчення проблеми передбачає розробку завдань, що сприятимуть засвоєнню студентами авіаційних вищих навчальних закладів фразеології радіообміну, зокрема термінів, уживаних у повідомленнях ATIS, спонукатимуть студентів до самостійної роботи 
з пошуку, вивчення і використання абревіатур, скорочень, усічень у повідомленнях ATIS.

\section{Література}

1. Снчева Г. Г. Лінгвокогнітивне моделювання процесу перекладу авіаційних термінів (на матеріалі англо-українських версій нормативно-технічної документації ICAO) : автореф. дис. ... канд. філол. наук / Г. Г. Снчева. - Одеса, 2011. - 24 с.

2. Збірник авіаційних скорочень / під ред. Вітряка А. М. - Кіровоград, 2010. - 176 с.

3. Кириченко А. Г. Мовні особливості англійського авіаційного радіотелефонного дискурсу / А. Кириченко // Вісник Львівського університету : Серія : Іноземні мови. 2013. - Вип. 21. - С. 63-68.

4. Ковтун О. В. Професійний дискурс «Радіообмін цивільної авіації» : функціональний i лінгвістичний аспекти / О.В.Ковтун // Наукові записки Вінницького державного педагогічного університету імені Михайла Коцюбинського. Серія : Філологія (Мовознавство) : зб. наук. пр. - Вінниця : ТОВ «Фірма Планер», 2014. - Вип. 19. - С. 307-312.

5. Кубрякова Е. С. Номинативный аспект речевой деятельности : [монография] / Е. С. Кубрякова. - [3-е изд.]. - М. : Изд-во ЛИБРОКОМ, 2010. - 160 с.

6. Мальковская Т. А. Англо-русские соответствия в языковой структуре радиообмена в режиме общения пилот-авиадиспетчер : автореф. дис. ... канд. филол. наук / Т. А. Мальковская. - Пятигорск, 2004. - 18 с.

7. Annex 10 to the Convention on International Civil Aviation / International Civil Aviation Organization. - Montreal, 2001. - Vol. II : Communication Procedures Including those with PANS status. $-2001 .-83$ p.

8. Chrystal D. Txtng: The Gr8 Db8. / David Crystal. - Oxford: Oxford University Press, 2008. - $256 \mathrm{p}$.

9. ICAO Manual of Radiotelephony (Doc 9432 AN/925) / International Civil Aviation Organization. - Montreal, 2006. - 106 p.

Стаття надійшла до редакиії 20.03.2015 p. 